\title{
Artesian Water in the
}

Malabar Coastal Plain of

\section{Southern Kerala, India}

GEOLOGICAL SURVEY WATER-SUPPLY PAPER 1608-D

Prepared in cooperation with the Geological Survey of India under the auspices of the United States Technical Cooperation Mission to India

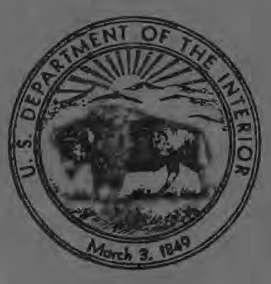




\section{Artesian Water in the}

\section{Malabar Coastal Plain of}

\section{Southern Kerala, India}

By G. C. TAYLOR, JR. and P. K. GHOSH

CONTRIBUTIONS TO THE HYDROLOGY OF ASIA AND OCEANIA

GEOLOGICAL SURVEY WATER-SUPPLY PAPER 1608-D

Prepared in cooperation with the Geological Survey of India under the auspices of the United States Technical Cooperation Mission to India

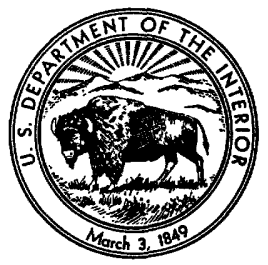


UNITED STATES DEPARTMENT OF THE INTERIOR

STEWART L. UDALL, Secretary

\section{GEOLOGIGAL SURVEY}

Thomas B. Nolan, Director 


\section{CONTENTS}

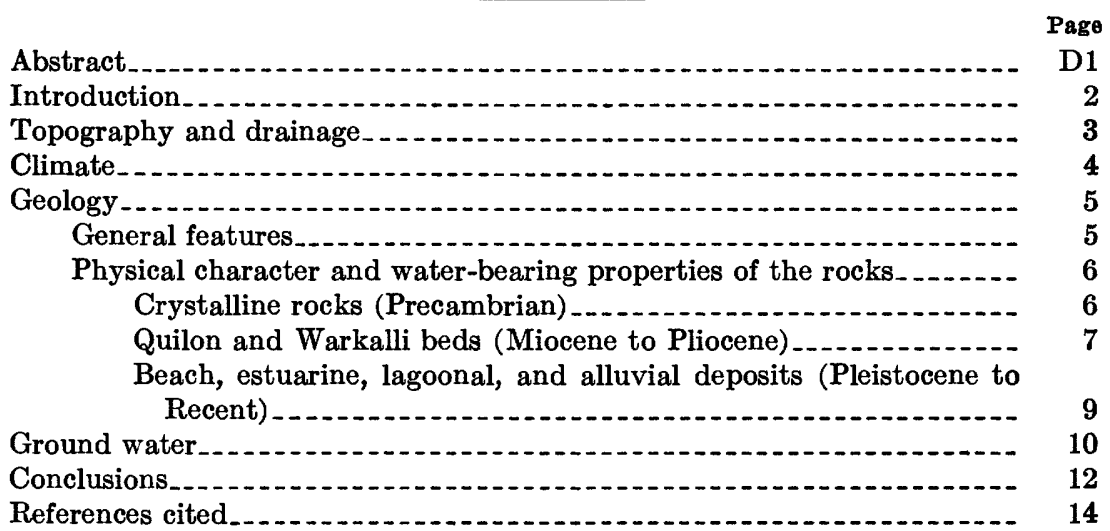

\section{ILLUSTRATIONS}

Prate 1. Map of southern Kerala

2. Geologic section along the coast of Kerala_......... In pocket

FIGURE 1. Index map of India

D3

\section{TABLES}

TABLE 1. Average monthly and annual rainfall, in inches, for stations in the coastal belt of Kerala.

2. Pressure head of water from the deepest water-bearing horizon and artesian flow in March 1954 from typical wells in the coastal plain of Kerala 



\title{
CONTRIBUTIONS TO THE HYDROLOGY OF ASIA AND OCEANIA
}

\section{ARTESIAN WATER IN THE MALABAR COASTAL PLAIN OF SOUTHERN KERALA, INDIA}

\author{
By G. C. TAYLOR, JR., and P. K. Ghosh
}

\begin{abstract}
The present report is based on a geological and hydrological reconnaissance during 1954 of the Malabar Coastal Plain and adjacent inland areas of southern Kerala to evaluate the availability of ground water for coastal villages and municipalities and associated industries and the potentialities for future development. The work was done in cooperation with the Geological Survey of India and under the auspices of the U.S. Technical Cooperation Mission to India.

The State of Kerala, which lies near the southern tip of India and along the eastern shore of the Arabian Sea, contains a total area of 14,937 square miles. The eastern part of the state is a rugged mountainous highland which attains altitudes of more than 6,000 feet. This highland descends westward through a piedmont upland to a narrow coastal plain, which reaches a maximum width of about 16 miles in the latitude of Shertallai. A tropical monsoon rain-forest climate prevails in most of Kerala, and annual rainfall ranges from 65 to 130 inches in the southern part of the coastal plain to as much as 200 inches in the highland.

The highland and piedmont upland tracts of Kerala are underlain by Precambrian metamorphic and igneous rocks belonging in large part to the so-called Charnockite Series. Beneath the coastal plain are semiconsolidated to unconsolidated sedimentary deposits whose age ranges from Miocene to Recent. These deposits include soft sandstone and clay shale containing some marl or limestone and sand, and clay and peat containing some gravel. The soft sandstone, sand, and gravel beds constitute important aquifers at depths ranging from a few tens of feet to 400 feet or more below the land surface. The shallow ground water is under water-table or unconfined conditions, but the deeper aquifers contain water under artesian pressure. Near the coast, drilled wells tapping the deeper aquifers commonly flow with artesian heads as much as 10 to 12 feet above the land surface.

The draft from existing wells in the coastal belt between Quilon and Alleppy was estimated at 1 to $1 \frac{1}{2}$ million imperial gallons a day. However, favorable conditions exist for considerable further ground-water development in the coastal plain provided that sufficient attention is given to the potential hazards of saltwater encroachment and local overdevelopment. It is estimated that the overall potential for development of water from wells is probably at least several tens of millions of gallons a day, and perhaps more, in the Malabar Coastal Plain of southern Kerala. Such a draft would have to be well dispersed to avoid overdevelopment and salt-water encroachment.
\end{abstract}




\section{INTRODUCTION}

Even though Kerala receives abundant rainfall that sustains the flow of numerous perennial streams, many coastal communities are separated from these sources by extensive brackish-water channels and lagoons that reach inland from the Arabian Sea. As a consequence, supplies of fresh water from surface sources in places are not adequate for increasing municipal and industrial requirements. The principal purpose of the present investigation was to evaluate the availability of ground water for coastal villages and municipalities and associated industries and to evaluate the ground-water potential for future development.

The present report is based on a geological and hydrological reconnaissance of the Malabar Coastal Plain and adjacent inland areas of southern Kerala during 1954 by the late Dr. P. K. Ghosh and Mr. M. S. Balasundaram, of the Geological Survey of India, and Mr. G. C. Taylor, Jr., of the U.S. Geological Survey. The field party is much indebted to Messrs. George Thomas, Ananta Krishnan, and K. K. Kartha, of the State of Kerala (formerly Travancore-Cochin), for facilities provided to carry out the work. They also greatly appreciate the help provided by J. D. Bayliss-Paul, who accompanied the field party and arranged visits to important points of interest. To all these officials the field party is indebted for furnishing well logs and related hydrologic data on wells put down by the Kerala Department of Waterworks and Drainage and the Port of Cochin.

The State of Kerala extends north from near the southernmost tip of India at Cape Comorin for some 350 miles almost to the latitude of Mangalore (fig. 1). On the north and east, Kerala is bordered by the States of Mysore and Madras and on the west and south by the Arabian Sea and the Indian Ocean. The total area of Kerala is 14,937 square miles, and the population is about $13 \frac{1}{2}$ million persons, most of whom live in the coastal belt. The chief products of Kerala are coffee, tea, rubber, pepper, and cardamom, which are grown on plantations in the Anaimalai and Cardamon Hills. Ebony, teak, rosewood, and sandalwood also are cut from forests in the same hills. Extensive groves of coconut palms, which yield coir and copra, and cashew nut trees are cultivated in the coastal plain. Monazite and ilmenite locally concentrated in beach sand are mined on the Malabar Coast. The largest city and the capital of Kerala is Trivandrum (population about 187,000). Other important cities are Alleppy, Cochin, Kozhikode, and Quilon; all these cities are seaports and trading centers for the products of the State. Small industries based on the processing of marine, agricultural, forest, and mineral products are in or near these cities. 


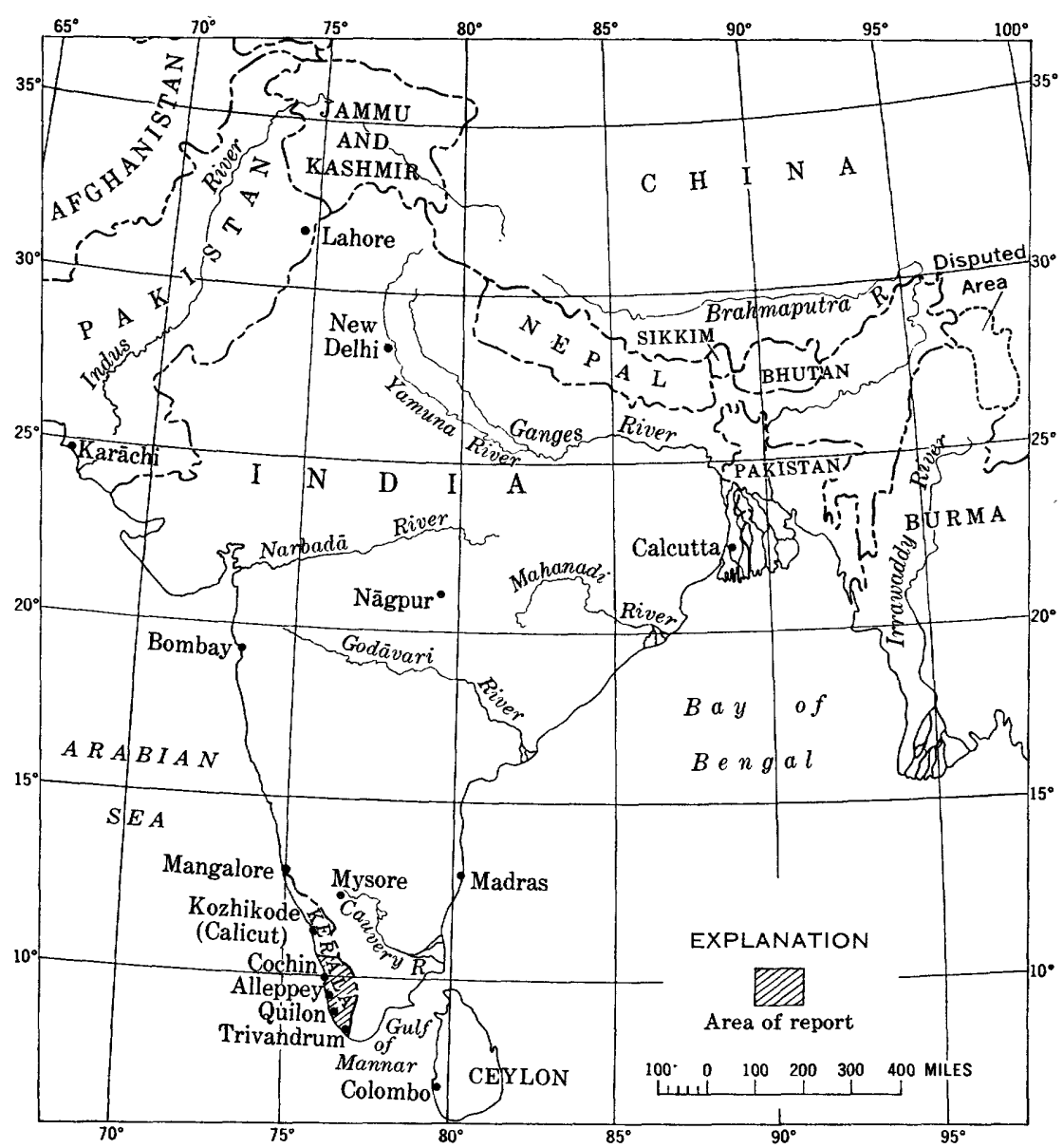

Fraorn 1.-Index map of India showing the location of the State of Kerala.

\section{TOPOGRAPHY AND DRAINAGE}

The eastern part of Kerala is a densely forested and rugged mountainous highland that includes parts of the Anaimalai and Cardamon Hills and their extensions almost as far south as Cape Comorin. This highland forms the backbone and drainage divide of the southern peninsula of India. To the west of this divide, streams flow to the Arabian Sea, and to the east they flow to the Bay of Bengal or the Gulf of Mannar. Along the crest of the divide, altitudes range from about 3,500 to 4,500 feet, but some peaks reach altitudes of more than 6,000 feet above sea level. The highest point on the divide is Anai Mudi (alt. $8,841 \mathrm{ft}$ ), which is also the highest point in peninsular India outside of the Himalayan region. The principal stream of 


\section{D4 CONTRIBUTIONS TO THE HYDROLOGY OF ASIA AND OCEANIA}

Kerala is the Periyar River, which drains a large area on the western slope of the Cardamon Hills and ends in a backwater estuary near Parur. Other important rivers are the Pambiyar and the Achonkovil (pl. 1).

Extending along the western margin of Kerala is a narrow palmclad coastal plain which stretches north for some 160 miles from near Trivandrum to the latitude of Ponnani and beyond (pl. 1). The coastal plain pinches out near Trivandrum and attains a maximum width of about 16 miles in the latitude of Shertalli. The plain rises gradually from sea level to inland altitudes of about 100 feet and along its inland margin ends rather abruptly against low bluffs of a westward-sloping and stream-dissected piedmont upland that in most places is capped by a thick blanket of laterite. Along the coast, a belt of sandy barrier beaches about 3 to 5 miles wide trends parallel to the coast line. The beaches rise generally from 10 to 20 feet above sea level and are commonly separated from one another by marshy sloughs or backwater channels which are generally interconnected with the sea or with brackish-water tidal lagoons. The largest of these lagoons is Vembanad Lake lying between Shertalli and Kottayam (pl. 1), and just north of Quilon is Asthamudi Lake, which opens directly on the sea. Both lagoons extend inland almost to the edge of the coastal plain. From Quilon south almost to the latitude of Trivandrum, the shoreline is marked by low sea cliffs that rise from 20 to 140 feet above the sea.

\section{CLIMATE}

According to Wladimir Köppen's classification (Trewartha, 1943, p. 332-344), most of Kerala has a tropical monsoon rain-forest climate. In the coastal zone, the mean annual temperature is about $80^{\circ} \mathrm{F}$, and mean monthly temperatures range from about $78^{\circ} \mathrm{F}$ in January to $84^{\circ} \mathrm{F}$ in April. In this climate there is a distinct dry season in which at least one month receives an average of less than 2.5 inches of rain. Most of the annual rainfall (table 1) occurs during the southwest monsoon, whose influence is felt from April until November. The dry season extends from December to March during the northeast monsoon. June is usually the wettest month and January or February the driest; however, even during the relatively short dry season, the soil moisture is always great enough to maintain active plant growth.

The annual rainfall in the coastal zone of southern Kerala ranges from about 65 to 130 inches (table 1), but owing to orographic effects, it increases progressively at higher altitudes on the western slopes of the Anaimalai and the Cardamom Hills. In some hill stations in the eastern part of the State, the annual rainfall is reported to reach or exceed 200 inches. Rainfall also increases progressively from south 
to north in the coastal zone. Irinjalakuda, for example, receives almost twice as much rainfall during the year as Trivandrum (table 1). Temperatures, prevailingly high in the coastal zone, become more equable with altitude.

\section{GEOLOGY}

\section{GENERAI FEATURES}

The piedmont upland and highland tracts of Kerala are composed of igneous and metamorphic rocks (King, 1882, p. 87-92) belonging in large part to the so-called Charnockite Series (Internat. Geol. Cong., 1956, p. 45-46) of Precambrian Archean age, but other undifferentiated crystalline rock groups of Precambrian age also occur in the state. Precambrian rocks also form the basement beneath sediments of the coastal plain at depths ranging from a few tens or less to several hundred feet below the land surface.

Underlying the coastal plain are semiconsolidated to unconsolidated sedimentary deposits whose age ranges from Miocene to Recent. These deposits include the Quilon beds (Internat. Geol. Cong., 1956, p. 219) of early Miocene (Burdigalian) age and the younger Warkalli beds (Internat. Geol. Cong., 1956, p. 278) of late Miocene (Pontian) to early Pliocene age. The Warkalli beds are considered to be equivalent to the Cuddalore Sandstone (Internat. Geol. Cong., 1956, p. 56) of the Coromandel Coast. Beach, estuarine, lagoonal, and alluvial deposits of Pleistocene to Recent age directly underlie most of the coastal plain. These deposits are thickest near the coast, but inland they gradually thin to a featheredge against the piedmont upland of Precambrian crystalline rocks. In well 1 (pl. 2), put down at Cochin, the sedimentary deposits above bedrock have a thickness of 631 feet, the maximum recorded in the coastal plain. Farther

TABLE 1.-Average monthly and annual rainfall, in inches, for stations in the coastal belt of Kerala

[Based on data prior to 1945 from the Meteorological Department of India]

\begin{tabular}{|c|c|c|c|c|c|}
\hline Average for- & Trivandrum & Quilon & Alleppy & Ernakulam & Irinjalakuda \\
\hline January . & 0.8 & 0.8 & 2.0 & 0.5 & 0.4 \\
\hline February & .8 & .8 & 2.1 & .8 & .4 \\
\hline March & 1.5 & 1.8 & 2.4 & 1.6 & 1.3 \\
\hline April & 4.6 & 5.3 & 5.1 & 4.5 & 3.5 \\
\hline May ..... & 8.8 & 10.9 & 12.6 & 10.6 & 11.8 \\
\hline June & 13.2 & 20.8 & 26.0 & 28.6 & 32.3 \\
\hline July & 7.8 & 15.2 & 19.8 & 24.0 & 30.3 \\
\hline August & 4.7 & 9.6 & 14.6 & 15.4 & 18. 2 \\
\hline September........ & 4.5 & 7.4 & 9.8 & 9.8 & 10.2 \\
\hline October........ & 10.7 & 11.7 & 12.2 & 13.8 & 14.1 \\
\hline November... & 7.0 & 8.5 & 10.2 & 5.6 & 7.0 \\
\hline December..... & 2.5 & 1.8 & 2.2 & 1.5 & 1.1 \\
\hline Year.............. & 66.9 & 94.6 & 119.0 & 116.7 & 130.6 \\
\hline
\end{tabular}


inland and 2 miles east, well 2 on Willingdon Island is reported to have reached bedrock at a depth of 404 feet.

Laterite cappings are widespread on the piedmont surface adjacent to the coastal plain, both on Precambrian rocks of the piedmont upland and on outcrop areas of Quilon and Warkalli beds. A laterite zone presumably of Pliocene to early Pleistocene age is also reported in several wells along the coast and is believed to mark the top of the Quilon and Warkalli sequence beneath the coastal plain. The laterite apparently represents a residual soil horizon developed during subaerial weathering of the parent rock under a monsoon type climate of alternating wet and dry seasons. The fact that the laterite zone dips northward in the line of section of plate 2 suggests that the top of the Quilon-Warkalli sequence has been downwarped in the vicinity of Cochin and possibly also farther to the north. At well 1 in Cochin the laterite zone is 225 feet below sea level, but in the vicinity of Warkalli near the southern end of the coastal plain the laterite at the top of the Quilon-Warkalli sequence is 50 feet or more above sea level.

\section{PHYSICAL CHARACTER AND WATER-BEARING PROPERTIES OF THE ROCKS}

\section{CRYSTALLINE ROCKS (PRECAMBRIAN)}

The Charnockite Series includes a whole suite of rocks ranging from felsic to ultramafic composition (Krishnan, 1956, p. 108-111). In these and other Precambrian crystalline rocks of Kerala, gneissic or schistose texture is common but granitoid or massive texture also occurs.

Along the road between Trivandrum and Attingal, the prevailing rock is a highly garnetiferous granite gneiss. At milepost $32 \%$ on the Attingal-Quilon road is a roadside quarry in hill 272, which lies about 11 miles east-southeast of Quilon. The rock here exposed is a fine-grained gray banded garnet granite gneiss having vertical lineation striking north-northwest. Subparallel to oblique to the gneissic banding are streaks of coarse garnet-epidote-biotite pegmatite. Similar rocks crop out along the highway near Chengannur and Changanacheri. At a quarry in Annakunnu hill about half a mile north of the municipal office of Kottayam are exposures of garnetsillimanite-biotite gneiss which contains stringers, porphyroblasts, and interbands of feldspar. At milepost $2 \%$ west of Alwaye on the Parur road are outcrops of banded quartz-feldspar granulite. From Alwaye north along the road to Trichur more mafic types of charnockite are common. In a well at the Trichur Traveller's Bungalow dark-gray medium to coarse-grained gneiss with predominant amphi- 
bole was found beneath some 35 feet of laterite. The rock is composed of quartz, plagioclase, biotite, amphibole, and cordierite(?). Weathered garnet granite is reported between depths of 631 and 646 feet in well 1 (pl. 1) at Cochin and between 404 and 510 feet in well 2 on Willingdon Island.

The regional water table and the zone of saturation in the area of Kerala east of the coastal plain are in Precambrian crystalline rocks. The circulation of water through these rocks occurs mainly in surficial mantles of rock disintegrated by weathering and through joints, sheeting, and other minor partings. The depth of rock weathering in places may be as great as 75 to 100 feet. Open wells dug in the crystalline rocks generally tap water in sufficient quantity for smallscale or domestic use at depths of less than 100 feet. Wells put down to greater depths in these rocks, however, seldom tap water in any greater quantity than that found above 100 feet. Deep drilling in these rocks to obtain substantial quantities of water is therefore generally futile.

\section{QUILON AND WARKALLI BEDS (MIOCENE TO PLIOCENE)}

The Quilon and Warkalli beds were first described by King (1882, p. 93-102) in the coastal belt between Quilon and Warkalli. The Quilon beds, from abundant fossil evidence, are assigned an early to middle Miocene age (Eames, 1950, p. 235-237) and the Warkalli beds a late Miocene to early Pliocene age. The Quilon and Warkalli together may be considered as a more or less continuous sedimentary sequence.

The Quilon and Warkalli beds have a gentle seaward (westerly) dip that is generally less than $2^{\circ}$. Available well logs indicate that the Quilon and Warkalli beds extend beneath most of the coastal plain but are covered by younger Pleistocene to Recent deposits, except in areas near Warkalli and Quilon and in a narrow fringe along the inland margin of the coastal plain. The lithologic character and the thickness of the Quilon and Warkalli beds beneath the coastal plain have been revealed in some detail by study of 11 drilled wells whose locations are shown on plate 1 , and whose logs are shown graphically on plate 2. Among these wells the greatest thickness of Quilon and Warkalli beds penetrated by the drill was at well 1 where the sequence is 415 feet thick. Wells 7,9 , and 12 did not reach the crystalline basement, but the thickness of the Quilon and Warkalli sequence is at least 307,377 , and 367 feet, respectively.

The Warkalli beds are exposed extensively near Warkalli for about 6 miles along the coast in sea cliffs which range from 20 to 140 feet in height. In the type area on the coast about $1 \frac{1}{2}$ miles west of 
Warkalli station the following section from top to bottom was observed by the writers.

Thickness (feet)

Laterite, spongy-textured, mottled red, yellow, and purple _.......... 10

Sandstone, semi-consolidated, friable, coarse- to medium-grained; currentbedded with quartz grit and a few lenses of clay shale and siltstone...-

Clay, carbonaceous; black and sandy clay containing 6-in. to 1-ft lenses of lignite . . . . . .

Sea level.

Farther inland near Warkalli station is an artificial cut in Warkalli beds made during construction of a navigation canal in 1880. Here almost 40 feet of soft medium- to coarse-grained yellowish-brown to pale-gray sandstone overlies about 50 to 60 feet of dense compact yellow-to-gray clay shale. About 51/2 miles north of Changanacheri and 1 mile west of the Chengannur-Changanacheri road, the following section of the Warkalli is exposed in a cut for a new navigation canal:

Thickness (feet)

Laterite, reddish-brown, highly ferruginous

Sandstone, soft, reddish-brown to buff _._.

Shale, clay, dark-gray to black, carbonaceous .

65

The Quilon beds have been described chiefly from outcrops in the vicinity of Quilon and in the vicinity of Padappakkara, which lies about 8 miles northeast of Quilon on a backwater of Asthamudi Lake. The beds include highly fossiliferous limestone, soft sandstone, gravel, sand and gravel, and sand and clay that attain an exposed thickness of at least 40 feet near Quilon (Krishnan, 1956, p. 498-499). Beneath the coastal plain, however, the Quilon beds thicken considerably, as indicated by well 11 at Chavara (pl. 2). A typical Quilon fauna is described from sediments in this well between depths of 170 and 190 feet, and beds of Quilon age are inferred to extend to a depth of at least 280 feet (Jacob and Sastri, 1949, p. 348).

As indicated by the well logs of plate 2, the top of the Quilon and Warkalli sequence is marked by a laterite zone (pl. 2) which is generally from about 5 to 20 feet thick. The laterite zone in well logs is generally reported as "laterite" or as red ferruginous sand and clay associated with white clay which may be kaolin or lithomarge. This zone is recorded in 9 of the 11 wells for which logs are available and may be virtually continuous beneath much of the coastal plain. The Quilon and Warkalli sequence as reported in wells generally comprises 
alternating beds of semiconsolidated clay, clay shale, sand or soft sandstone, sand and gravel, and gravel whose colors range through white, yellow, and gray. Carbonaceous clay and thin beds of black and brown peat or lignite are also common. Soft limestone or marl is also present at a few places, as for example in wells 1 and 12 . Marine fossils including corals, lamellibranchs, and gastropods are recorded at one or more zones in the Quilon and Warkalli sections of most of the wells. Foraminifera and other microfauna, not recorded by drillers logs, also are probably present. As suggested by the logs, the Quilon and Warkalli beds were apparently deposited in shallowwater marine and coastal lagoonal environments which evidently alternated frequently.

The clay, clay shale, and sandy clay members of the Quilon and Warkalli beds are relatively impervious and yield little or no water to wells. On the other hand, the sand and gravel, coarse sand, and friable sandstone members are pervious and are generally waterbearing where they lie in the regional zone of saturation. These water-bearing beds of the Quilon and Warkalli sequence constitute the most important aquifers in the coastal plain of Kerala. The position and thickness of Quilon and Warkalli aquifers of gravel, sand, and soft sandstone penetrated in 11 wells along the coast are shown graphically on plate 2 .

\section{BEACH, ESTUARINE, LAGOONAL, AND ALLUVIAL DEPOSITS (PLEISTOCENE TO RECENT)}

The coastal plain is directly underlain by beach, estuarine, lagoonal, and alluvial deposits of Pleistocene to Recent age in a belt extending from 1 mile or less to about 13 miles inland. As suggested by the well logs on plate 2, the thickness of these deposits above the QuilonWarkalli beds ranges from 20 feet or less to about 235 feet. Overlying the laterite zone at the top of the Quilon-Warkalli sequence are alternating unconsolidated white, gray, and black clay, sand, and sand and gravel containing some marine fossils and a few layers of peat that are assigned a Pleistocene age. The thickness of the Pleistocene deposits ranges from a featheredge at the south end of the coastal plain to about 170 feet in well 1 at Cochin. Unconsolidated beach deposits including the well-known monazite sands form the Recent deposits. These deposits, as reported in the logs of plate 2, range from 20 to 45 feet thick.

The Pleistocene deposits contain several water-bearing sand or sand and gravel beds that are probably moderately productive. These aquifers, though penetrated by existing drilled wells, have not been screened and developed, possibly because the aquifers do not have sufficient artesian head to produce natural flow at the land 
surface or possibly because the Pleistocene aquifers in places may contain brackish water.

The Recent beach deposits of the coastal belt are composed principally of unconsolidated sands that are moderately permeable and generally contain potable water. Shallow dug and driven wells, generally less than 20 feet deep, yield water sufficient for domestic purposes from these deposits.

\section{GROUND WATER}

The principal source of recharge to the aquifers of the coastal plain is probably the downward percolation of water from rain that falls on the emerged areas of the Tertiary and Quaternary deposits (pl. 1). Some recharge, however, may also occur above tidal limit from rivers and streams that cross the coastal plain. As indicated in table 1, the annual rainfall on the Malabar Coast of Kerala ranges from 65 to more than 130 inches. Thus, the quantity of water available for recharge is large during most of the year and probably exceeds the infiltration capacity of the soil during much of the wet season. Because the Quilon-Warkalli aquifers and also the Pleistocene aquifers tapped by the existing wells in the coastal belt have gentle seaward dips, the same aquifers gradually rise landward and are probably at or near the surface in the interior part of the coastal plain. Recharge to the Quilon-Warkalli aquifers probably takes place principally in the marginal belt near the inland limit of the coastal plain. The Pleistocene aquifers are likely to contain brackish water in those parts of the coastal plain where outcrop areas lie under or adjacent to tidal lagoons, such as Asthamudi and Vembanad Lakes, or to other backwater channels. However, it is inferred that the Pleistocene aquifers to the east of the backwater channels in the stretch of coastal plain between Asthamudi and Vembanad Lakes receive recharge from rainfall or streams and therefore also contain fresh water. A shallow body of fresh ground water which is probably recharged locally, chiefly by direct infiltration from rain, occurs in the Recent beach deposits along the coastal belt to the west of the backwater channels and tidal lagoons.

The fresh water that enters the Quilon-Warkalli aquifers along the inland margin of the coastal plain moves seaward along flow lines which slope in the same direction as the hydraulic gradient. Water from these aquifers probably discharges naturally by upward leakage into the Pleistocene deposits in the shore zone. The Quilon-Warkalli aquifers pass beneath the shallow tidal lagoons and backwater channels at substantial depth, and are apparently protected by a cover of 
younger Pleistocene deposits. For this reason they do not appear to be exposed, except perhaps locally in the Quilon area, to brackishwater contamination from these tidal water bodies.

Water probably enters the Pleistocene aquifers somewhat west of the recharge zone of the Quilon-Warkalli aquifers and also moves westward, probably to discharge directly into the sea. Because of the position of the recharge zone, the Pleistocene aquifers in places are likely to receive brackish water from the tidal lagoons and backwater channels and may transmit this water down the hydraulic gradient. Thus, it is possible, although substantive proof is lacking, that the Pleistocene deposits in the vicinity of and to the west of Asthamudi and Vembanad Lakes may contain brackish water.

The fresh, shallow ground water in the Recent deposits of the coastal belt probably moves westward to the sea and eastward to the tidal lagoons and backwater channels from a longitudinal ground-water divide. This divide probably lies about midway between the shoreline and the nearest inland tidal water body.

In all the coastal belt, the water of Quilon-Warkalli aquifers occurs under confined or artesian conditions and rises in wells to levels a few feet below or above the land surface. Among the 11 wells shown on plate 2, artesian pressure heads of the deepest screened aquifers of the Quilon-Warkalli sequence ranged from approximately $17 \frac{11}{2}$ feet above sea level, in well 8, to 6 feet above sea level, in well 3, in March 1954; however, the artesian head in the deeper aquifers at well 3 was probably substantially depressed by pumping from wells 4 and 5 near Alleppy. The aquifers in the Pleistocene sequence are reported to have somewhat lower artesian heads in the coastal belt than those in the Quilon-Warkalli sequence, although the difference is no more than a few feet at most wells. The water in the Recent deposits along the coast is under unconfined or water-table conditions and does not rise in shallow wells significantly above the level at which it is tapped.

As shown in table 2, all the wells with positive heads in the coastal belt were flowing at the land surface in March 1954 with natural discharge ranging from a few gallons to 32 Igpm (imperial gallons per minute). The flowing wells were all put down by the State of Kerala to supply the relatively modest domestic water requirements of village cantons. Wells 4 and 5 furnish the municipal water supply of Alleppy whose normal requirement in 1954 ranged from about 500,000 to 750,000 Igpd (imperial gallons per day). Both wells were fitted with deep well turbine pumps. Well 4 (Punnapra 2) yielded $240 \mathrm{Igpm}$ with a 16-foot drawdown and Well 5 (Punnapra 1) yielded $365 \mathrm{Igpm}$, also with a drawdown of 16 feet. Well 5 was temporarily out of use 
TABLE 2.-Pressure head of water from the deepest water-bearing horizon and artesian flow in March 1954 from typical wells in the coastal plain of Kerala

\begin{tabular}{|c|c|c|c|}
\hline Well & $\begin{array}{c}\text { Altitude of } \\
\text { land surface } \\
\text { (feet above } \\
\text { mean sea } \\
\text { level) }\end{array}$ & $\begin{array}{c}\text { Pressure head } \\
\text { (feet above } \\
(+) \text { or below } \\
(-) \text { land } \\
\text { surface) }\end{array}$ & $\begin{array}{c}\text { Artesian } \\
\text { flow at } \\
\text { land surface } \\
\text { (Igpm) }\end{array}$ \\
\hline $\begin{array}{l}1 \\
6 \\
6 \\
6\end{array}$ & $\begin{array}{r}10 \\
9 \\
18 \\
12 \\
12 \\
10 \\
10 \\
10 \\
5 \\
10 \\
10\end{array}$ & $\begin{array}{r}? \\
0 \\
-12 \\
-9 \\
-9 \\
+4 \\
+51 / 2 \\
+71 / 2 \\
+11 \\
+4 \\
+3\end{array}$ & $\begin{array}{r}? \\
\text { Barely flows } \\
0 \\
0 \\
\mathbf{0} \\
\mathbf{5} \\
\mathbf{1 3} \\
\mathbf{3 0} \\
27 \\
\mathbf{3 2} \\
\mathbf{6}\end{array}$ \\
\hline
\end{tabular}

in March 1954, and well 4 was being pumped some 18 to 20 hours a day to supply approximately 250,000 Igpd for a rationed municipal supply. Well 3 was being completed for the Alleppy supply at the time of the writers' fieldwork.

In the coastal plain (pl. 1) the only substantial ground-water draft, actual or proposed in 1954, was from wells 4 and 5 near Alleppy. It is evident, however, from the geologic and hydrologic characteristics of wells in the cross section of plate 2 that moderately productive wells can also be developed from Quilon-Warkalli aquifers elsewhere in the coastal plain and that yields comparable to or better than those of wells 4 and 5 could be obtained. For optimum yield, such wells would have to be constructed with proper casing, screens, gravel packing, and thorough development. Although no data on the chemical quality of the water were available in March 1954, it was observed that the waters from wells 3 through 12 (pl. 2) were generally pleasing to the palate and suitable for domestic and municipal purposes.

\section{CONCLUSIONS}

The Tertiary and Quaternary sedimentary sequence of the Malabar Coastal Plain of Kerala contains several moderately productive aquifers distributed through the Quilon and Warkalli beds and the Pleistocene to Recent deposits. These aquifers, as indicated on plate 2, range from a few tens of feet to 400 feet or more below the land surface. In the coastal belt where natural ground-water discharge takes place, the shallow aquifer in the Recent deposits is under water-table conditions, but in the Pleistocene deposits and in the Quilon and Warkalli beds the aquifers contain water under artesian pressure that increases progressively with depth. In the inland areas of the coastal plain where recharge occurs, however, the shallow aquifer is also under water-table conditions; but the deeper aquifers, although artesian, probably have lower heads than the water table. 
As of March 1954 the rate of withdrawal from deep and shallow wells, including artesian flow, was estimated at 1 to $1 \frac{1}{2}$ million Igpm in the coastal belt between Quilon and Alleppy. Elsewhere, in the coastal plain of the map area (pl. 1), there is wide but small-scale use of shallow ground water for domestic purposes from dug wells but little development of the deeper aquifers from drilled wells. Thus, there exists a favorable potential for fairly large use of the deeper aquifers for municipal and industrial purposes, particularly in the area between Vembanad and Asthamudi Lakes and also to the east of Vembanad Lake in the area between Ernakulam and Kottayam (pl. 1). Exploration by test drilling is needed, however, to establish the water quality, stratigraphic position, artesian head, and yield of the deeper aquifers in these areas. In the coastal belt between Alleppy and Cochin and also on Vypin Island, test drilling is needed to verify the presence or absence of brackish water as well as the position and yield of the aquifers. The strip of coastal plain about 3 to 5 miles wide that lies west of the contact (pl. 1) with the Precambrian rocks of the piedmont and between the Periyar River estuary and Kunnamkulam is also believed to have favorable conditions for groundwater withdrawals. Test drilling is also needed in this area to establish the geologic and hydrologic characteristics of the aquifers.

Although the coastal plain generally has favorable conditions for further ground-water development, many of the populated centers where wells might be drilled are near the sea or tidal lagoons and backwater channels. Fresh-water aquifers in wells drilled within a mile or two of these salty or brackish-water bodies may be exposed to contamination by encroachment from these bodies should excessive withdrawal and local overdevelopment of the aquifers occur. This hazard needs to be considered carefully before extensive development is undertaken. Where feasible, those wells from which substantial withdrawals are anticipated for industrial or municipal use should be located perhaps 2 miles or more from tidal water bodies. Wells intended for domestic, village, or other small-scale use probably could be located where needed, provided the draft from an individual well were no more than a few tens of gallons per minute.

The overall potential for development of water from wells is probably several tens of millions of gallons a day, and perhaps more, in the Malabar Coastal Plain of southern Kerala. Such a total draft would have to be well dispersed to avoid the eventuality of local overdevelopment and salt-water encroachment. 


\section{D14 CONTRIBUTIONS TO THE HYDROLOGY OF ASIA AND OCEANIA}

\section{REFERENCES}

Eames, F. E., 1950, On the ages of certain upper Tertiary beds of peninsular India and Ceylon: Geol. Mag., v. 87, no. 4, p. 233-252.

International Geological Congress, 20th, Mexico 1956, Lexique Stratigraphique International: v. 3, pt. 8, 404 p.

Jacob, K., and Sastri, V. V., 1949, Miocene Foraminifera from Chavara, near Quilon, Travancore: India Geol. Survey Recs., v. 82, pt. 2, p. 342-353.

King, W., 1882, General sketch of the geology of the Travancore state: India Geol. Survey Recs., v. 25, pt. 2, p. 87-93. 1882, The Warkalli beds and reported associated deposits at Quilon in Travancore: India Geol. Survey Recs., v. 25, pt. 2, p. 93-102.

Krishnan, M. S., 1956, Geology of India and Burma: The Madras Law Journal Office, Madras, $555 \mathrm{p}$.

Trewartha, G. T., 1943, An introduction to weather and elimate: McGraw-Hill Book Co., New York, 545 p. 